\title{
Review of unconventional hydrocarbon resources: production technologies and opportunities for development
}

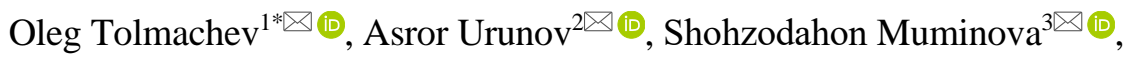 \\ Galina Dvoichenkova ${ }^{4,5 \square(1)}$, Ilya Davydov ${ }^{6 \otimes(1)}$ \\ ${ }^{1}$ Bauman Moscow State Technical University, Moscow, 105005, Russian Federation \\ ${ }^{2}$ State University of Management, Moscow, 109542, Russian Federation \\ ${ }^{3}$ Polytechnic Institute of Tajik technical University. Akad. M.S. Osimi, Dushanbe, 734042, Tajikistan \\ ${ }^{4}$ Institute of Comprehensive Exploitation of Mineral Resources of Russian Academy of Sciences, Moscow, 111020, Russian Federation \\ ${ }^{5}$ Mirny Polytechnic Institute (Branch) of North-Eastern Federal University, Moscow, 678170, Russian Federation \\ ${ }^{6}$ Moscow State Institute of International Relations (University) of the Ministry of Foreign Affairs of the Russian Federation, Moscow, \\ 119454, Russian Federation \\ *Corresponding author: e-mail oltom@bmstu.ru, tel. +9776587150
}

\begin{abstract}
Purpose. Study the state of modern technologies for the extraction of unconventional hydrocarbon resources and determine the prospects for their development.

Methods. The method of qualitative and quantitative analysis of scientific literature, data from the U.S. Energy Information Administration, national reports on the Extractive Industries Transparency Initiative standard, as well as open Internet sources, are used in the research. Structurally, the research consists of a sequential analysis of the main types of unconventional hydrocarbon resources. The analysis of each type of unconventional hydrocarbon resources is to determine its main geological characteristics, conditions of occurrence, prospecting-predicting criteria and peculiarities, technologies of recovery, country (geographic) localization and statistical data on production dynamics.

Findings. The research presents a systematization of the main types of unconventional hydrocarbon resources, such as oil and gas of shale strata, tight sands gas (basin-central gas type and tight sands gas), methane gas of coal fields, bituminous and oil sands, oil from oil shale, as well as their sequential analysis. The definitions of the main types of unconventional hydrocarbon resources according to Russian and English terminology are synchronized. Depending on the type of unconventional hydrocarbon resources, the conditions for their occurrence, prospecting-predicting criteria and diagnostic properties, country (geographic) localization are determined. The research presents the world experience in the recovery of unconventional hydrocarbon resources (North America, Europe, and the Asia-Pacific region), as well as the dynamics of shale gas and oil recovery (using the example of the United States).
\end{abstract}

Originality. A sequential systematic analysis of unconventional hydrocarbon resources, depending on their type, has been made.

Practical implications. The main objectives have been determined for solving the problem of using the unconventional hydrocarbon sources potential, which can lead to the conclusions about the prospects for the unconventional hydrocarbon resources recovery. It is advisable to assess the necessity of studying unconventional hydrocarbon resources in countries oriented on the use of traditional resources.

Keywords: oil, gas of shale strata, tight sands, basin-central gas type, bituminous sands, oil shale, shale oil

\section{Introduction}

The problem of prospecting, exploration and recovery of oil and gas from unconventional sources (rocks of coalbearing strata, shale, consolidated sandstones, crystalline complexes and massifs) is extremely relevant today and is being discussed in the academic sciences society, as well as by specialists (often not only by them) of the oil-and-gas industry. However, while the full-scale production of oil and gas from unconventional sources has already begun in the North American continent, in other regions of the world this kind of unconventional hydrocarbon reserves development is either at an early stage or is completely ignored [1]-[4].

Exploration and development of oil and gas from unconventional sources should be considered as an important direction for the development of the global oil-and-gas industry in the context of the annual narrowing of opportunities for dis- 
covering new traditional oil-and-gas fields. At the same time, the implementation of oil-and-gas production projects contains significant risks associated with high mining costs and fluctuations in market prices.

The necessity of research into the world experience of prospecting, exploration and recovery of oil and gas from unconventional sources is primarily conditioned by the need to study possible competitors in the hydrocarbon market.

When analysing the experience of foreign countries in the study and development of unconventional reservoirs [6], [7], the following main types of unconventional hydrocarbon resources, which are being developed at the industrial level, primarily in the USA and Canada, have been distinguished:

1. Oil and gas of shale strata.

2. Tight sands gas (basin-central gas type and tight sands gas).

3. Methane gas of coal fields.

4. Bituminous, oil sands.

5. Oil from oil shale.

Geological conditions for occurrence of unconventional accumulations of the so-called non-convection gas, in contrast to traditional (convection) gas, can be characterized as an accumulation of natural gas contained in rocks with low permeability. Unconventional gas reservoirs have both general characteristics and substantially different ones. The main general characteristics that characterize all types of unconventional hydrocarbon are as follows:

- gas accumulations are distributed regionally; gas presence is not associated with geological traps (structural, stratigraphic and lithological);

- petrophysical properties vary over a wide range within the strata (porosity and permeability);

- drilling of a horizontal well and the use of multi-stage hydraulic fracturing in a horizontal well, as well as the use of other complex extraction technologies (quarrying, intrastratal borehole method of mining) [8].

The main distinguishing peculiarity characterizing all types of unconventional hydrocarbons, such as shale rocks, coal and oil shale, is the source rock, which is capable of generating hydrocarbons, since it can accumulate and store organic matter in the required amount [9].

Experience of extraction in American shale basins evidences that each field has completely unique geological peculiarities, exploitation characteristics, as well as significantly different extraction problems, therefore, requires an individual scientific approach. For a radical change in the geological concept about unconventional reservoirs, new actual laboratory data and scientific-analytical developments are required. When studying shale rocks, global companies use a range of geological, geochemical, geophysical and mechanical parameters to analyse shale gas/oil potential as well to assess reserves [10].

The main problem in studying a shale gas basin is not determining the shale gas occurrence, but determining the rock quality.

The world practice of prospecting for oil and gas from unconventional reservoirs has determined a new approach to the search for promising areas. The strata in sedimentary cover capable of generating hydrocarbons can be identified by quantitative criteria, namely:

- the presence of argillaceous strata containing sapropelic or humus organic matter;

- increased organic matter content of more than 1.5-2\% with a thickness of at least $10 \mathrm{~m}$;
- thermal maturity of rocks sufficient for hydrocarbons generation, which is determined by the vitrinite reflectance at $\mathrm{R}^{\circ}$ from 0.8 to 1.2 ;

the rock composition should include the amount of argillaceous materials not more than $50 \%$;

- ratio of prospective deposits to reducing geochemical facies [11].

Research of scientists [12] has revealed that the phenomenon of inhomogeneous hydrophobization is the main factor of gas accumulation in dense rocks, primarily in black shale (both as a result of the generation of bitumoids by kerogen, and as a result of the presence of syngenetic coal and bitumen organic matter). It is this factor initiates the processes of capillary suction of methane from different sources (catagenetic generation of it by kerogen, water-soluble methane from groundwater, jet migration from great depths). This makes it possible not only to understand the reason for the phenomenon of this discrepancy, but also to propose new, more reliable criteria for prospecting and exploration of shale, basin-central gas, and coal gas [13].

The purpose of the paper is a comprehensive analysis of the state of technology for recovery of unconventional hydrocarbon resources.

The purpose necessitates setting of the following objectives: analyse the state of development, conditions of occurrence, extraction technologies for various types of unconventional hydrocarbon resources, such as oil and gas of shale strata; tight sands gas; bituminous and oil sands; oil from oil shale.

\section{Methods}

The method of qualitative and quantitative analysis of scientific literature, data from the U.S. Energy Information Administration, national reports on the Extractive Industries Transparency Initiative standard, as well as open Internet sources, are used in the research. At the first stage, statistical information is selected on the main types of unconventional hydrocarbon resources.

Structurally, the research consists of a sequential analysis of the main types of unconventional hydrocarbon resources, such as oil and gas of shale strata, tight sands gas (basincentral gas type and tight sands gas), methane gas of coal fields, bituminous and oil sands, oil from oil shale.

At the second stage of research, the authors, based on the experts' opinion (interviews, express surveys, reviews from scientific peer-reviewed journals Scopus and Web of Science over the past 10 years), have analysed each type of the unconventional hydrocarbon resources. The analysis involved the determining $Z$ of the main geological characteristics depending on conditions of occurrence, prospectingpredicting criteria and peculiarities, extraction technologies, country (geographic) localization and statistical data on production dynamics.

At the third stage of the study, the collected information is processed, with its arrangement according to the degree of significance, the construction of histograms, tables and the interpretation of the results obtained. In particular, if at least one criterion of each type of the unconventional hydrocarbon resources is not sufficiently described in terms of completeness, this criterion is excluded from the comparison for all types of resources. On the one hand, this enables to compare the types of unconventional hydrocarbon resources according to the same criteria, making the study systematic, as well as 
to monitor for the dynamics of changes for each resource type. On the other hand, this approach places some restrictions on the research results, since the interpretation is made without taking into account all possible criteria that could be used. The authors acknowledge that the research is limited due to the inability to obtain access to additional sources of information.

\section{Results and discussion}

In accordance with the objectives set, this section presents the generalized results of the analysis of the state of development, conditions of occurrence, technologies of recovery for various types of unconventional hydrocarbon resources.

\subsection{Oil and gas of shale strata}

According to the definition in the work [14], gas from shale strata is an unconventional industrial type of flammable natural gas, which is characterized by immobility (low mobility), occurs in a closed pore space or in a sorbed state in an impermeable shale host rocks. It is recovered due to the inflow of hydrocarbon fluid from producing wells through the fractured-pore space of an artificial reservoir, which is formed by using the hydraulic fracturing technology or other technologies for deconsolidation of productive reservoirs.

As the United States experience evidences, shaly pelitomorphic rocks, which are called black shale, are gas-bearing. In total, in terms of production in North America, there are two types of gas fields [15].

The first type includes most of the fields known in the United States - Barnet, Marcellus, etc. These are large (thousands of $\mathrm{km}^{2}$ ) areal of Palaeozoic black shale occurring at shallow depths (up to $1500 \mathrm{~m}$ ). Their development has an extensive character.

The areas of the second type of deposits (Haynesville USA, Horn River, Montey - Canada) are much smaller, and the depths of occurrence are much greater. The flow rates of wells are higher and more stable, which is conditioned by the specifics of geothermal and thermobaric conditions. If for the fields of the first type, the current temperatures and pressures are below the maximum, the shale-gas system is stabilized after maximum heating and the gas generation processes do not currently occur. While, the fields of the second type are characterized by active current generation of gas. Because of this, the porosity and degree of fracture opening are much higher in them, despite the significant $(3600-4500 \mathrm{~m}$ and more) depth of occurrence.

Genetically, gas from shale strata is a gas of organic origin and hydrocarbon composition (mainly methane - up to 96\%), formed as a result of catagenetic transformations of dispersed organic matter (DOM) in shale strata of sedimentary formations. It is accumulated directly in gas-generating shale seams or migrates short distances within a shale stratum [15].

The rocks containing the shale strata are sedimentary rocks with a predominance of an argillaceous component (up to $50 \%$ ), shale (laminated) texture, beneficiated with dispersed organic matter (from 1 to $25 \%$ ), which, according to the degree of catagenetic transformations, is capable of generating and accumulating hydrocarbon gases.

Thus, the shale gas is formed as a result of the kerogen (organic matter) degradation, the share of which from the total volume of finely dispersed sedimentary rock, mainly argillite, can vary from 1 to $25 \%$. The shale texture is pre- dominantly laminated, sometimes massive. That is, the presence of gas from shale requires the presence of organic matter - kerogen. Shale, containing organic matter, is both an unconventional natural reservoir and a place of shale gas formation. Shale gas in shale mainly occurs in a sorbed state and also in fractures, as in bituminous coal. The sorption properties of gaseous shale directly depend on the amount of kerogen in the source rock, and this gas can also be sorbed by the argillaceous minerals of the shale.

The most important prospecting-predicting criteria and peculiarities of gas-bearing shale strata, depending on the geological conditions of formation and mining-andgeological conditions of occurrence [16]:

- the presence of lithological and stratigraphic complexes of sedimentary rocks beneficiated with dispersed organic matter, represented by shale and argillite with a DOM content from 1 to $25 \%$;

- the degree of catagenetic transformations of DOM in shale strata corresponds to the main phase of gas formation, that is, the vitrinite reflectance is from 0.8 to $2.5 \%$;

- in terms of porosity and permeability factors, shale is almost impermeable and in traditional oil-and-gas geology are referred to cap rocks (fluid seals);

- the content of argillaceous and hydromicaceous components in shale strata does not exceed 50\%, taking into account the mining-engineering conditions of development, the content of the quartz component provides rocks fragility sufficient for artificial deconsolidation;

- the presence in shale rocks of carbonaceous plant detritus, as well as veins, films and drops of bituminous matter;

- presence of methane and its homologues in core samples;

- increased electrical resistance of gas-saturated productive reservoirs relative to similar, but water-saturated rocks in other wells or other depth intervals of the studied well;

- increased radioactivity according to data of gamma ray logging and gamma-gamma logging;

- extended time according to acoustic logging;

- decreased water saturation, which does not exceed $45 \%$.

The above prospecting-predicting criteria and peculiarities are not final. An important regional factor in the search for shale gas is the presence of sedimentary strata with a high genetic potential for the generation of hydrocarbons.

The search and exploration of hydrocarbon deposits in sedimentary strata are always aimed at identifying a reservoir for their accumulation in rocks with reservoir porosity and permeability parameters favourable for recovery. At the same time, argillite (argillaceous slate), in contrast to modern concepts, should act as a shielding stratum. The first data about the role of shale rocks as a reservoir came from foreign countries - the United States and others.

In North America, search and development of unconventional gas are conducted in shale of different ages and limitations (Table 1).

The beginning of gas recovery from coal and oil shale (Barnett Shale and others) in the United States was stimulated by economic policy. In 1980, the US Congress introduced a policy of financial incentives for producers of fuels obtained from non-convection sources called Nonconventional Fuels Tax Credit [17].

In the United States, the convection fields extraction, which peaked in 1973 (615 billion $\left.\mathrm{m}^{3}\right)$, was systematically reduced, gas imports grew rapidly, and the reserves of convective fields began to decline. 
Table 1. Characteristics of shale in North America [18]

\begin{tabular}{|c|c|c|c|c|c|}
\hline No. & Name & Age of occurrence & Upper shield & Lower shield & Geographic localization \\
\hline 1. & Marcellus Shale & Middle Devonian & $\begin{array}{c}\text { Shale } \\
\text { (Hamilton Group) }\end{array}$ & $\begin{array}{c}\text { Limestone } \\
\text { (Tristates Group) }\end{array}$ & $\begin{array}{c}\text { States New York, Pennsylvania, } \\
\text { Virginia, Ohio }\end{array}$ \\
\hline 2. & Barnett Shale & $\begin{array}{c}\text { Sediments } \\
\text { Mississippian }\end{array}$ & $\begin{array}{c}\text { Limestone } \\
\text { Marble Falls }\end{array}$ & $\begin{array}{l}\text { Limestone } \\
\text { Chappel }\end{array}$ & $\begin{array}{c}\text { Fort Worth Basin in the } \\
\text { northern area of Texas }\end{array}$ \\
\hline 3. & Fayetteville Shale & $\begin{array}{c}\text { Sediments } \\
\text { Mississippian }\end{array}$ & Limestone Pitkin & $\begin{array}{l}\text { Sandstone } \\
\text { Batesville }\end{array}$ & $\begin{array}{c}\text { Arkoma Basin of northern } \\
\text { Arkansas and eastern Oklahoma }\end{array}$ \\
\hline 4. & $\begin{array}{c}\text { Haynesville Shale } \\
\text { (Haynesville Bossier) }\end{array}$ & Upper jurassic & $\begin{array}{l}\text { Sandstone Cotton } \\
\text { Valley Group }\end{array}$ & $\begin{array}{c}\text { Limestone } \\
\text { Smackover Formation }\end{array}$ & $\begin{array}{c}\text { Salt basin in northern Louisiana } \\
\text { and eastern Texas }\end{array}$ \\
\hline 5. & The Woodford Shale & Devonian & $\begin{array}{l}\text { Limestone } \\
\text { Osage Lime }\end{array}$ & $\begin{array}{l}\text { Undifferentiated } \\
\text { layers }\end{array}$ & $\begin{array}{l}\text { South of the Oklahoma } \\
\text { central area }\end{array}$ \\
\hline 6. & Antrim Shale & Late Devonian & $\begin{array}{c}\text { Shales } \\
\text { Bedford Shale }\end{array}$ & $\begin{array}{c}\text { Limestone Squaw } \\
\text { Bay Limestone }\end{array}$ & $\begin{array}{l}\text { Northern area of the } \\
\text { Michigan Peninsula }\end{array}$ \\
\hline 7. & New Alabany Shale & $\begin{array}{l}\text { Upper Devonian- } \\
\text { lower mississippian }\end{array}$ & $\begin{array}{l}\text { Limestone Rockford } \\
\text { Limestone }\end{array}$ & $\begin{array}{l}\text { Limestone North } \\
\text { Vernon Limestone }\end{array}$ & $\begin{array}{l}\text { South-eastern area of the } \\
\text { Illinois state, south-western } \\
\text { Indiana and north-western } \\
\text { Kentucky }\end{array}$ \\
\hline
\end{tabular}

The Nonconventional Fuels Tax Credit was implemented with a purpose to develop its own reserves of non-convection gas, which were previously used to an insignificant extent, since their development had previously been unprofitable. Soon the downtrend in gas production was stopped, and since 1987 , gas recovery has started to grow, reaching on the eve of the crisis in 2008 a level close to the level of the early 1970s. In the United States of America, 70\% of shale gas reserves are related to the Barnett Basin in Texas, and $80 \%$ of the resources are in two new basins: Haynesville and Marcellus [19].

In Canada, until recently, the shale gas was extracted in the provinces of Alberta and Saskatchewan (Colorado Group), in the province of New Brunswick (Horton Bluff Group), between Montreal and Quebec, along the range of the Appalachian Mountains (Utica Group), in north-eastern British Columbia (Horn River Basin) [20].

In 2009, the "shale boom" reached Europe, where shale is promising in southern Sweden, in the Bonenci Depression in South-West Germany, in the Lower Saxony basin in Germany, in the Parisian and South-Eastern basins in France, in the Vienna Basin, in the Mako Basin in Hungary, shale of the Baltic and Lublin-Podlaskie basins in Poland, and shale in the Cantabrian basin of northern Spain [21].

More than 40 companies were involved into search for unconventional gas in Europe. For example, Royall Dutch Shell searched in Sweden, Exxon Mobil, Conoco Philips and Chevron in Poland. In Austria, OMW Company began exploring a prospective basin near Vienna, composed of Upper Jurassic Mikulov marls. In Bulgaria, the American companies Chevron and Integrity Towers planned the shale gas fields' development in the north-eastern area of Novi Pazar, and the shale gas resources in Bulgaria were estimated at 25 billion $\mathrm{m}^{3}$. In Spain, Realm Energy, cooperating with Halliburton Consulting, has assessed shale sedimentary basins in Spain. After a detailed assessment, the company has submitted 10 applications for five separate sedimentary basins, covering an area of $8903 \mathrm{~km}^{2}$. Currently, Realm Energy officially has two permits with a total area of $858 \mathrm{~km}^{2}$ in the Cantabrian Basin in Northern Spain. In Germany, Exxon Mobil Company acquired a license for a 750000-acre site in Lower Saxony where shale gas prospecting is conducted [22].

Poland is one of the most promising countries in Europe in terms of prospecting for shale gas. The Lower Palaeozoic Basin on the western slope of the East European Craton has been defined as one of the most attractive regions for shale gas exploration in Europe. In Poland, concessions have been issued for the search for shale gas, but so far none have been issued for its recovery [23].

In Hungary, in 2009 Exxon Mobil drilled the first shale gas wells in the Mako Trough. Having failed to achieve positive results, Exxon Mobil Company abandoned its project in Hungary, as it did not find industrial shale gas reserves. In Sweden, Shell Oil is licensed to explore the early Palaeozoic Alum Shale bituminous shale in the southern area of the country (Skene region) as a possible shale gas source. The organic matter content in the rocks of this formation reaches $20 \%$. Shale gas reserves in Sweden are estimated at 300 billion $\mathrm{m}^{3}$ [24].

The Asia-Pacific region is also actively prospecting for shale gas. For example, in Australia, Beach Petroleum Limited in 2010 announced plans to drill for shale gas in the Cooper Basin. However, the cost of energy produced from cheap Australian coal is twice lower than that of similar shale GJ. Today, the issue of shale gas development is under consideration by the ecological and economic services of the country [25].

In India, Reliance Industries Limited (RIL) and other companies are interested in the possibility of developing shale gas, but this is complicated by the legal framework, which does not provide for land leases for gas recovery from unconventional sources. India has huge shale deposits in the Indo-Gangetic Plain, Assam, Gujarat, Rajasthan and many coastal regions. In Durgapuri, an "unlimited reserve" of shale gas was identified at a depth of $1770 \mathrm{~m}$ in the rocks of the Damodar Basin on an area of 1250-1300 km² [26].

As early as in March of 2011, the US Energy Information Agency assessed the shale gas technical reserves in China at 36.1 trillion $\mathrm{m}^{3}$, which is significantly higher than the US shale gas reserves, estimated at 24.4 trillion $\mathrm{m}^{3}$ [27].

North Africa also has significant shale gas potential for commercial production in the Illzi Basin (Algeria), Ghadames Basin (Tunisia, Algeria, Western Libya) and West Risha (Jordan). Morocco and Western Algeria also have significant shale gas potential, which is characterized by high commercial risks. As for South Africa, shale gas reserves here account for $7.3 \%$ of the world's proven reserves. Thus, large shale gas resources have been found in the Karoo Basin. However, the government imposed a moratorium on "fracking" in Karoo after extensive protests from the public and environmentalists in April 2011 [28]. 
Russia, Venezuela and the Middle East also possess huge reserves of shale gas, but their traditional gas potential is so great that there is no strategic need for exploration and even more so for the development of cost demanding shale gas fields.

\subsection{Tight sands gas}

Tight sands gas is a gas mixture contained in lowporosity and low-permeability reservoirs and shale. This gas, unlike traditional gas resources of all types, is not related to traditional traps, but is located throughout the entire central submerged part (in depressions, basins) of the oil-and-gas basin, occupying large areas (up to $8000 \mathrm{~km}^{2}$ ). Within large areas of such gas accumulation, there are also ordinary gas deposits. Tight sands gas reservoirs are formed in the same way as conventional gas reservoirs; however, the rock saturated with gas from the source rocks has very low permeability.

According to the International Energy Agency, the working definition for tight sands gas is a gas from reservoirs that cannot be developed with traditional technologies of vertical drilling due to poor flow rate. Typically, such rocks have better gas flow rates than shale and, therefore, a higher concentration of hydrocarbons per unit surface area.

Among the gas of tight sands, there are:

a) basin-central gas;

b) tight sands gas.

Basin-central gas is natural gas, the accumulations of which are not associated with traditional structural or lithological-stratigraphic traps, but occupy the central submerged parts of oil-and-gas basins (depressions, saddles), which have regional and zonal distribution within the basin, predominately in consolidated terrigenous, argillaceous and carbonaceous rocks. The collecting properties of deep-seated consolidated rocks are, of course, secondary.

Accumulations of basin-central gas are fundamentally different from conventional hydrocarbon fields. They occupy the central, most submerged parts of oil-and-gas basins, spread over large areas, and contain areas of good reservoirs with large and very large volumes of gas, which is genetically related to the rocks in which it was formed and accumulated. Therefore, prediction of the basin-central gas in new regions must be related to the conditions of its generation and accumulation.

For today, accumulations of basin-central gas have been explored and mined in the Mesozoic basins of the Rocky Mountains and Palaeozoic basins on the North American platform.

On the basis of published materials [29], [30], diagnostic properties have been analysed and determined for the identification of basin-central gas clusters:

1. The basin-central gas accumulations are not associated with traditional structural or lithological-stratigraphic local traps, but occupy the central submerged parts of the oil-and-gas basin (depressions, saddles), which have regional and zonal distribution, occupying large areas (up to $8000 \mathrm{~km}^{2}$ and more).

2. The reservoirs are often composed of sandstones. The following reservoirs are distinguished:

a) coastal-marine sheet types reservoirs (sandstones, siltstones, carbonates) that respond well to hydraulic fracturing;

b) lenticular, deposited by a system of flows (sandstones, siltstones), in which the response to hydraulic fracturing is ambiguous;

c) shallow marine (sandstone, siltstone, chalk, argillaceous slate).
Gas accumulation reservoirs are traced in the form of single seams or thick (up to $1000 \mathrm{~m}$ ) strata. More than one reservoir is often observed within the same area. Gas is recovered in areas with improved reservoirs, by the terminology of American specialists, in "sweet spots", but still mainly by using intensification methods.

3 . The porosity varies from less than 5 to $25 \%$, preferably less than 5\% - in sandstones, argillaceous slates, carbonates; permeability is mostly less than $0.1 \mathrm{md}$.

In basin-central gas clusters, two types of dense reservoirs are distinguished:

a) those that occur at shallow (up to $1220 \mathrm{~m}$ ) depths and have high porosity and low permeability due to the fact that they are composed of small grains, their porosity is original;

b) low-porous reservoirs, which occur at significant (more than $2000 \mathrm{~m}$ ) depths and are dense due to diagenetic and catagenetic transformations.

Low-porous reservoirs are almost always naturally fractured, and fracture permeability is an order of magnitude higher than that of the source rock itself. Both types of dense reservoirs are characterized by high capillary pressure. The low-porous type includes coastal-marine and lenticular reservoirs, and the highly-porous type includes shallow marine sheet reservoirs.

4. Basin-central gas reservoirs are often under abnormal pressure in zones of abnormally high reservoir pressure or abnormally low reservoir pressure. In some basins, high and low pressures can occur simultaneously.

5. Accumulations of basin-central gas are characterized by low water content of the productive stratum; because of the low rocks permeability, the gas cannot move due to buoyancy, therefore its accumulations do not have traditional gas-water contacts and are mainly located hypsometrically below the water-saturated reservoir. In this case, the upper water-saturated reservoirs are separated from the lower gasbearing reservoirs by dense diagenetically and catagenetically transformed rocks.

6. Shields of basin-central gas accumulations, in general, are not associated with lithological and stratigraphic boundaries, but are caused by a combination of capillary forces with factors of catagenetic (secondary) processes that influence the porosity and permeability properties of rocks, especially the upper shield. The lower shield is more often subordinated to lithological boundaries.

7. American geologists usually consider the surface hypsometry of the abnormally high reservoir pressure (or abnormally low reservoir pressure) as the surface of distributing the basin-central gas accumulation. The surface depth of the basin-central gas occurrence in the basins of the United States and Canada varies from 305 to $4575 \mathrm{~m}$. In abnormally high reservoir pressure zones, the depth is usually more than 2000-3000 m, and in zones with abnormally low reservoir pressure, it is less than $800 \mathrm{~m}$.

8 . When, based on the above mentioned diagnostic properties, the spatial distribution of the basin-central gas accumulation in the regional (zonal) plan is determined, the second stage of solving this problem begins - the search for areas of improved reservoirs, that is, the search for "sweet spots", from which industrial gas flows can be obtained at lower costs. First of all, American experts recommend identifying gas accumulations in the upper $300-400 \mathrm{~m}$, where it is more likely to find the best reservoirs than in deep horizons. 
There are two types of "sweet spots" - sedimentary and structural. Sedimentary type includes sea bars, channel sand bodies, deltaic sediments, etc. where reservoirs of increased porosity and permeability are most likely located. For this purpose, borehole cores, logging and seismic data are used. "Sweet spots" of the structural type are areas of increased rocks fracturing, caused by the formation of fractures, which are able to provide increased gas inflows to wells. These areas are determined from the analysis of discontinuous faults and folding.

The most favourable condition for implementation of the second stage, when predicting the basin-central gas accumulations, is the identification of areas with a combination of sedimentary and structural "sweet spots"-reservoirs on the same area.

9. Based on American experience, the well testing and gas recovery from dense reservoirs almost always require inflow intensification. Hydraulic fracturing is more often used, for which special technologies have been developed, but only to a depth of $4500 \mathrm{~m}$. In addition, due to the fact that natural fractures most often have a vertical direction, drilling of inclined and horizontal wells is used.

None of the above criteria (diagnostic properties of identifying the basin-central gas accumulations) is universal and determinative. Figure 1 presents the dynamics of shale and tight sands gas production in the United States for the period of 2004-2018 (at the end of the year) (based on materials [31]).

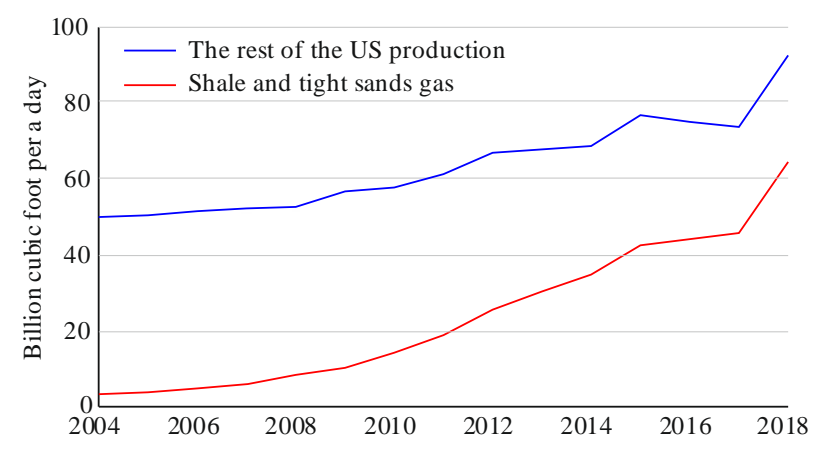

Figure 1. Dynamics of shale and tight sands gas production in the United States for the period of 2004-2018, billion cubic foot per a day

In December 2018, the United States shale and tight sands natural gas production was about 65 billion cubic feet per day (Bcf/d) $(70 \%$ of the total gas production in the USA) [32]. Ten years earlier, in December 2008, shale gas accounted for $16 \%$ of total US gas production.

\subsection{Coal bed methane}

At present, the coal seams are considered as unconventional gas reservoirs in the world. Methane from coal deposits is assessed not only as an associated mineral contained in coal seams and host rocks, but also as a separate mineral, the recovery of which is possible in economically feasible volumes, provided that hydraulic seam fracturing is used. Coalbearing formations are significant sources and places of methane accumulation in the earth's crust. The gas mixture accompanying coal seams and located rocks is contained in coal-bearing deposits and is formed as a result of biochemical and physical processes of plant material transformation into coal. The gas content in coal depends on the depth of the seams bedding, the degree of coal metamorphism, the condi- tions of occurrence (structure) and many other factors. Coal seams contain methane in three states: free, sorbed and dissolved (in water). Most of its volume (over $88 \%$ ), sorbed by coal, is concentrated in seams and dissipated in the rock massif; about $10 \%$ is in a free state, filling pores and fractures; about $2 \%$ is dissolved in water.

Real success in the production of coal mine methane has been achieved in the United States. Industrial production of coal mine methane began in this country in 1984, when 280 million $\mathrm{m}^{3}$ of gas was obtained from 284 wells. Until 1997, 7300 wells had already been drilled, and the production volume reached 32 billion $\mathrm{m}^{3}$, accounting for $6 \%$ of the total volume of gas consumption. In 2000, the number of wells drilled reached 8000, and the production volume was 35 billion $\mathrm{m}^{3}$. Most of the gas produced in the US coal fields is obtained by using the methods of intensification of the gas inflow into wells, in particular, by the method of hydraulic seam fracturing. At that time, 1.8 billion $\mathrm{m}^{3}$ was mined and used from the fields of operating mines. According to the latest data, the total reserves of coal mine methane in the United States are assessed at 27 trillion $\mathrm{m}^{3}$, and recoverable reserves, according to various estimates, range from 1.35 to 3.8 trillion $\mathrm{m}^{3}$.

\subsection{Bituminous sands. Oil shale}

Bituminous sands are a fossil fuel, organic part of which is represented by naturally occurring bitumen. Bituminous sands are composed of a mixture of sand, crude oil and water, in other words, these are rocks saturated with oil or other bitumen.

The main parameters of the oil-bearing sands:

1. Mineral composition.

2. Petrophysical characteristics (porosity, permeability, particle-size distribution)

3. Oil base.

4. Geochemical oil composition.

5. Viscosity. The bitumen viscosity in the sands is so great that, in turn, affects the dynamics of the fluid. Thus, to extract bitumen from sand, it is necessary to add a solvent to liquefy it.

6. Hydrophylic property. Oil sands can be saturated with water.

Hydrophilic sands are characterized by a film of water between the sand and oil. They are effective for removing bitumen, because in a hydrophilic rock, capillary pressure in the rock-hydrocarbon-water system tends to prevent the hydrocarbon fluid movement from coarse-grained rocks to finegrained ones, at the contact of which a capillary barrier arises of a certain force.

Oleophilic sands are sands in which oil is in direct contact with sand grains. In oleophilic rocks, the opposite tendency of hydrocarbon movement is observed, where, under the action of capillary pressure, hydrocarbons penetrate into the smallest possible voids, and the smallest pores are saturated with hydrocarbons, which complicates the process of their recovery.

To extract bitumen, drilling of vertical and horizontal wells is used, with the help of which underground processing of bitumen with hot steam is performed [34].

Oil shale is an argillaceous, marlaceous or bituminous limestone rock of brown, reddish brown, chocolate, dark gray, and sometimes light yellow colors, that can split into tiles. When fresh, it can be cut with a knife and form fine 
particles. It is easily ignited by a match. During combustion, soot is emitted with a characteristic odor of bitumen. The chemical composition of oil shale is as follows: carbon $60-75 \%$, hydrogen $-6-10 \%$, oxygen, nitrogen, sulfur $-14-$ $20 \%$, the rest is heavy metals and various compounds. Oil shale contains organic matter (kerogen) in an amount from $10-15$ to $60-80 \%$. Oil shale is an organic-mineral formation that is formed under water conditions [35], [33].

Extraction of oil from shale is an industrial process of unconventional oil production. The kerogen recovered from oil shale is converted to shale oil through pyrolysis, hydrogenation or thermal treatment. The shale oil obtained is used as fuel-oil residue or as a refinery feedstock after purification from sulfur and nitrogen impurities and addition of hydrogen [36]-[39].

Figure 2 presents the dynamics of shale oil production in the United States for the period of 2004-2018 (at the end of the year) [31].

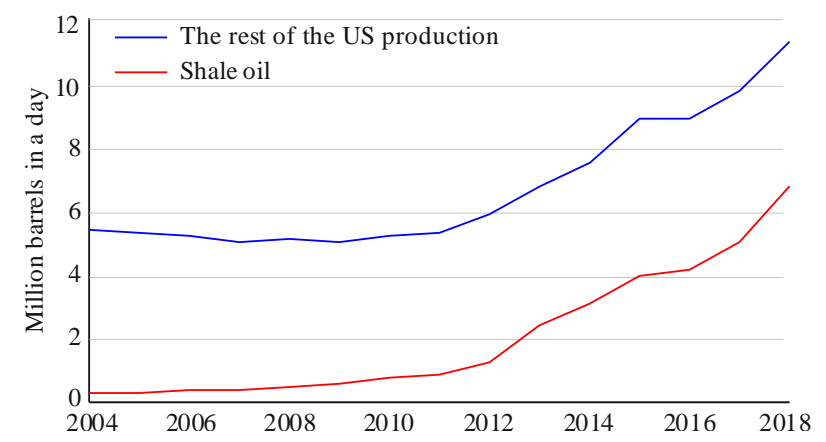

Figure 2. Dynamics of shale oil production in the United States for the period of 2004-2018, million barrels in a day

In December 2018, U.S. shale oil production was about 7 million barrels per day (b/d) of crude oil $(60 \%$ of total US oil production). Ten years before, in December 2008, shale oil accounted for about $12 \%$ of total U.S. oil production.

The main shale oil resources (24-25 trillion tons of crude shale oil) are concentrated in the USA (states of Colorado, Utah, Wyoming) and are associated with the Green River formation. There are large deposits of oil shale in Brazil, China, smaller - in Bulgaria, Great Britain, Russia, Germany, France, Spain, Austria, Canada, Australia, Italy, Sweden, on the territory of the former Yugoslavia.

\section{Conclusions}

In Russia, deposits of unconventional hydrocarbon resources are not being explored, because in the coming decades it is not appropriate in the presence of huge reserves and resources of traditional oil and gas. Until recently, the issues of prospecting, exploration, and obtaining oil and gas inflows from unconventional sources were under study. In addition to attracting finance, advanced technologies and equipment, in order to solve scientific and practical problems of prospecting, exploration and recovery of this type of hydrocarbons, it is necessary not only to provide a solid scientific approach with the involvement of specialists from scientific and industrial enterprises, but also have an economic substantiation for such a research, since such works are new both for the region and for the state.

Nevertheless, the research results of prospecting and exploration works in the world make it possible to identify the main objectives for solving the problem of using the resource potential of unconventional hydrocarbon sources:

- collecting, generalization and analysis of data on world hydrocarbon resources associated with unconventional deposits and reservoirs of their accumulation and storage: geological structure of basins and separate deposits, their composition, lithological peculiarities of rocks, development technologies;

- geological and lithological-stratigraphic analysis of potential structures and strata;

- analysis of drilling materials and geophysical studies of wells within these structures;

- study of the material composition, petrophysical, petrographic, mineralogical peculiarities, their systematization and type assignment as possible gas production objects;

- study of the form of hydrocarbons occurrence, their component composition, isotopy;

- analyzing capabilities of geophysical methods, in particular 3D modeling, for a preliminary assessment of the potential significance of unconventional hydrocarbon sources;

- creation of a geological and geochemical model of the natural gas fields formation;

- development of scientific bases for assessing hydrocarbon resources and reserves;

- geological and economic assessment of the expediency of using hydrocarbon deposits to meet the energy needs of the state;

- identification, preparation and environmental-economic assessment of priority objects for exploration and extraction of deposits;

- implementation of pilot projects for prospecting, exploration and extraction of hydrocarbons in the priority sites.

\section{References}

[1] Arthur, M.A., \& Cole, D.R. (2014). Unconventional hydrocarbon resources: prospects and problems. Elements, 10(4), 257-264. https://doi.org/10.2113/gselements.10.4.257

[2] Łukańko, Ł., \& Macuda, J. (2016). The influence of prospecting unconventional hydrocarbon reservoirs on acoustic climate. $A G H$ Drilling, Oil, Gas, 33(4), 747-755. https://doi.org/10.1016/s18763804(19)60244-2

[3] Sheng, J.J. (2015). Increase liquid oil production by huff-n-puff of produced gas in shale gas condensate reservoirs. Journal of Unconventional Oil and Gas Resources, (11), 19-26. https://doi.org/10.1016/j.juogr.2015.04.004

[4] Ursul, A, \& Ursul, T. (2015). Towards a global sustainable future. Philosophy and Cosmology, (15), 110-160.

[5] Law, B.E., Ulmishek, G.F., Clayton, J.L., Kabyshev, B.P., Pashova, N.T., \& Krivosheya, V.A. (1998). Basin-centered gas evaluated in DnieperDonets basin, Donbas foldbelt. Oil and Gas Journal, 96(47), 74-78.

[6] Strpić, K., Miličević, M., \& Kurevija, T. (2017). Development of tight oil resources in the USA: Exploitation costs and effect of macroeconomic indicators in a volatile oil price environment. Rudarsko Geolosko Naftni Zbornik, 32(3), 23-33. https://doi.org/10.17794/rgn.2017.3.3

[7] Parraguez Kobek, M.L., Ugarte, A., \& Campero Aguilar, G. (2015). Shale gas in the United States: Transforming energy security in the twenty-first century. Norteamérica, 10(1), 7-38. https://doi.org/10.20999/nam.2015.a001

[8] Bocora, J. (2012). Global prospects for the development of unconventional gas. Procedia - Social and Behavioral Sciences, (65), 436-442. https://doi.org/10.1016/j.sbspro.2012.11.145

[9] Bryndzia, L.T., \& Braunsdorf, N.R. (2014). From source rock to reservoir: The evolution of self-sourced unconventional resource plays Elements, 10(4), 271-276. https://doi.org/10.2113/gselements.10.4.271

[10] Ben E. Law. (2002). Basin-centered gas systems. American Association of Petroleum Geologists Bulletin, 86(11), 1891-1919. https://doi.org/10.1306/61 eeddb4-173e-11d7-8645000102c1865d

[11] Burwen, J., \& Flegal, J. (2013). Unconventional gas exploration \& production. Case studies on the Government's role in energy technolo- 
gy innovation. Washington, United States: American Energy Innovation Council.

[12] Shanley, K.W., Cluff, R.M., \& Robinson, J.W. (2004). Factors controlling prolific gas production from low-permeability sandstone reservoirs: Implications for resource assessment, prospect development, and risk analysis. American Association of Petroleum Geologists Bulletin, 88(8), 1083-1121. https://doi.org/10.1306/03250403051

[13] Haiko, H., Saik, P., \& Lozynskyi, V. (2019). The philosophy of mining: Historical aspect and future prospect. Philosophy \& Cosmology, (22), 76-90. https://doi.org/10.29202/phil-cosm/22/6

[14] Joskow, P.L. (2013). Natural gas: From shortages to abundance in the United States. American Economic Review, 103(3), 338-343. https://doi.org/10.1257/aer.103.3.338

[15] Allen, D.T., Torres, V.M., Thomas, J., Sullivan, D.W., Harrison, M., Hendler, A., \& Seinfeld, J.H. (2013). Measurements of methane emissions at natural gas production sites in the United States. Proceedings of the National Academy of Sciences, 110(44), 17768-17773. https://doi.org/10.1073/pnas.1304880110

[16] Song, W., Yao, J., Ma, J., Couples, G.D., Li, Y., \& Sun, H. (2018). Pore-scale numerical investigation into the impacts of the spatial and pore-size distributions of organic matter on shale gas flow and their implications on multiscale characterisation. Fuel, (216), 707-721. https://doi.org/10.1016/j.fuel.2017.11.114

[17] Metcalf, G.E. (2014). The economics of energy security. Annual Review of Resource Economics, 6(1), 155-174. https://doi.org/10.1146/annurev-resource-100913-012333

[18] Review of Emerging Resources: U.S. Shale Gas and Shale Oil Plays. (2011). Washington, United States: Energy Information Administration.

[19] Rassenfoss, S. (2011). From flowback to fracturing: Water recycling grows in the Marcellus shale. Journal of Petroleum Technology, 63(07), 48-51. https://doi.org/10.2118/0711-0048-jpt

[20] Chong, J., \& Simikian, M. (2014). Shale gas in Canada: Resource potential, current production and economic implications. Ottawa, Canada: Parliamentary Information and Research Service.

[21] Shale gas in Europe: Revolution or evolution? (2015). London, United Kingdom: EYGM Limite.

[22] Cremonese, L., Ferrari, M., Flynn, M.P., \& Gusev, A. (2015). Shale gas and fracking. Potsdam, Germany: Elsevier. https://doi.org/10.1016/c20140-00197-9

[23] Johnson, C., \& Boersma, T. (2013). Energy (in) security in Poland the case of shale gas. Energy Policy, (53), 389-399. https://doi.org/10.1016/j.enpol.2012.10.068

[24] Boersma, T., \& Johnson, C. (2012). The shale gas revolution: U.S. and EU policy and research agendas. Review of Policy Research, 29(4), 570-576. https://doi.org/10.1111/j.1541-1338.2012.00575.x

[25] Warner, D. (2011). Shale gas in Australia: a great opportunity comes with significant challenges. Preview, 2011(155), 18-21. https://doi.org/10.1071/pvv2011n155p18

[26] Mishra, S., Mendhe, V.A., Varma, A.K., Kamble, A.D., Sharma, S., Bannerjee, M., \& Kalpana, M.S. (2018). Influence of organic and inorgan- ic content on fractal dimensions of Barakar and Barren Measures shale gas reservoirs of Raniganj basin, India. Journal of Natural Gas Science and Engineering, (49), 393-409. https://doi.org/10.1016/j.jngse.2017.11.028

[27] Chen, X., Liu, Z., Liang, X., Zhang, Z., Zhan, T., Zhu, H., \& Lan, J. (2018). The shale gas revolution in China - problems and countermeasures. Earth Sciences Research Journal, 22(3), 215-221. https://doi.org/10.15446/esri.v22n3.74390

[28] Chapman, G., Wait, R., \& Kleynhans, E. (2015). The governance of shale gas production in South Africa. South African Journal of International Affairs, 23(1), 69-88. https://doi.org/10.1080/10220461.2015.1096211

[29] McCullagh, T., \& Hart, B. (2010). Stratigraphic controls on production from a basin-centered gas system: Lower Cretaceous Cadotte Member, Deep Basin, Alberta, Canada. American Association of Petroleum Geologists Bulletin, 94(3), 293-315. https://doi.org/10.1306/08260908137

[30] Popov, M.A., Nuccio, V.F., Dyman, T.S., Gognat, T.A., Johnson, R.C., Schmoker, J.W., \& Bartberger, C.E. (2001). Basin centered gas systems of the U.S. New York, United States: Open-File Report. https://doi.org/10.3133/ofr2001135

[31] EIA adds new play production data to shale gas and tight oil reports. (2019). Washington, United States: Energy Information Administration.

[32] Shale's new dawn: Prospects for MENA fracking Production of unconventional gas has risen substantially. (n.d.). Louisiana, United States: Louisiana Oil and Gas Association.

[33] Vorob'ev, A., Chekushina, T., \& Vorob'ev, K. (2017). Russian national technological initiative in the sphere of mineral resource usage. Rudarsko Geolosko Naftni Zbornik, 32(2), 1-8. https://doi.org/10.17794/rgn.2017.2.1

[34] Larter, S.R., \& Head, I.M. (2014). Oil sands and heavy oil: Origin and exploitation. Elements, 10(4), 277-283. https://doi.org/10.2113/gselements.10.4.277

[35] Jakobsson, K., Söderbergh, B., Snowden, S., Li, C.-Z., \& Aleklett, K. (2012). Oil exploration and perceptions of scarcity: The fallacy of early success. Energy Economics, 34(4), 1226-1233. https://doi.org/10.1016/j.eneco.2011.11.003

[36] Crawford, P., Biglarbigi, K., Dammer, A., \& Knaus, E. (2008). Advances in world oil-shale production technologies. SPE Annual Technical Conference and Exhibition, (6), 1401-4111. https://doi.org/10.2118/116570-ms

[37] Churin, V., Vysotskaya, N., Sizova, Y., Danilina, E., \& Gorelov, D. (2019). Distribution of mineral extraction revenue: overview of international practice. Mining of Mineral Deposits, 13(2), 66-74. https://doi.org/10.33271/mining13.02.066

[38] Dudin, M.N., Lyasnikov, N.V., Protsenko, O.D., \& Tsvetkov, V.A. (2017). Quantification and risk assessment of hydrocarbon resources development projects in the Arctic region. Economic Policy (in Russian), 12(4), 168-195. https://doi.org/10.18288/1994-5124-2017-4-07

[39] Barkan, M.S., \& Kornev, A.V. (2017). Prospects for the use of associated gas of oil development as energy product. International Journal of Energy Economics and Policy, 7(2), 374-383.

\section{Огляд нетрадиційних вуглеводневих ресурсів: технології видобутку та можливості для розвитку}

\section{О. Толмачов, А. Урунов, Ш. Мумінова, Г. Двойченкова, І. Давидов}

Мета. Дослідити стан сучасних технологій видобутку нетрадиційних вуглеводневих ресурсів і визначити перспективи їх розвитку.

Методика. У дослідженні використано метод якісного та кількісного аналізу наукової літератури, даних Управління енергетичної інформації США (U.S. Energy Information Administration), національних звітів за стандартом Ініціативи прозорості видобувних галузей (Extractive Industries Transparency Initiative), відкритих джерел у мережі Інтернет. Структурно дослідження складалося у послідовному аналізі основних видів нетрадиційних вуглеводневих ресурсів. Аналіз кожного з видів нетрадиційних вуглеводневих ресурсів складався з визначення його основних геологічних характеристик, умов розміщення, пошуково-прогнозних критеріїв і ознак, технологій видобутку, крайової (географічної) локалізації та статистичних даних щодо динаміки видобутку.

Результати. У дослідженні представлена систематизація основних видів нетрадиційних вуглеводневих ресурсів - нафти і газу сланцевих товщ, газу ущільнених пісковиків (газу центрально-басейнового типу й газу ущільнених пісковиків), метанового газу вугільних родовищ, бітумінозних і нафтових пісків, нафти з горючих сланців - та здійснено їх послідовний аналіз. Синхронізовано визначення понять основних видів нетрадиційних вуглеводневих ресурсів з російської та англійської термінологій. Залежно від виду нетрадиційних вуглеводневих ресурсів визначені умови їх розміщення, пошуково-прогнозні критерії та діагностичні ознаки, крайова (географічна) локалізація. У дослідженні показано світовий досвід видобутку нетрадиційних вуглеводневих ресурсів (Північна Америка, Європа, Азіатсько-Тихоокеанський регіон), а також динаміка видобутку сланцевих газу й нафти (на прикладі США).

Наукова новизна. Здійснено послідовний системний аналіз нетрадиційних вуглеводневих ресурсів залежно від їх виду.

Практична значимість. Визначено основні завдання для вирішення проблеми використання ресурсного потенціалу нетрадиційних вуглеводневих джерел, які дозволять зробити висновки щодо перспективності видобутку нетрадиційних вуглеводневих ресурсів, а також оцінити необхідність дослідження нетрадиційних вуглеводневих джерел у країнах, орієнтованих на використання традиційних ресурсів.

Ключові слова: нафта, газ сланщевих товщ, ущільнені пісковики, центрально-басейновий газ, бітумінозні піски, горючі сланці, сланцева нафта 


\section{Обзор нетрадиционных углеводородных ресурсов: технологии добычи и возможности для развития}

\section{О. Толмачёв, А. Урунов, Ш. Муминова, Г. Двойченкова, И. Давыдов}

Цель. Исследовать состояние современных технологий добычи нетрадиционных углеводородных ресурсов и определить перспективы их развития.

Методика. В исследовании использован метод качественного и количественного анализа научной литературы, данных Управления энергетической информации США (U.S. Energy Information Administration), национальных отчетов по стандарту Инициативы прозрачности добывающих отраслей (Extractive Industries Transparency Initiative), открытых источников в сети Интернет. Структурно исследование состояло в последовательном анализе основных видов нетрадиционных углеводородных ресурсов. Анализ каждого из видов нетрадиционных углеводородных ресурсов состоял из определения его основных геологических характеристик, условий размещения, поисково-прогнозных критериев и признаков, технологий добычи, страновой (географической) локализации и статистических данных по динамике добычи.

Результаты. В исследовании представлена систематизация основных видов нетрадиционных углеводородных ресурсов нефти и газа сланцевых толщ, газа плотных песчаников (газа центрально-бассейнового типа и газа плотных песчаников), метанового газа угольных месторождений, битуминозных и нефтяных песков, нефти из горючих сланцев - и осуществлен их последовательный анализ. Синхронизированы определения основных видов нетрадиционных углеводородных ресурсов по русской и английской терминологиям. В зависимости от вида нетрадиционных углеводородных ресурсов определены условия их размещения, поисково-прогнозные критерии и диагностические признаки, страновая (географическая) локализация. В исследовании показан мировой опыт добычи нетрадиционных углеводородных ресурсов (Северная Америка, Европа, Азиатско-Тихоокеанский регион), а также динамика добычи сланцевых газа и нефти (на примере США).

Научная новизна. Осуществлен последовательный системный анализ нетрадиционных углеводородных ресурсов в зависимости от их вида.

Практическая значимость. Определены основные задачи для решения проблемы использования ресурсного потенциала нетрадиционных углеводородных источников, которые позволят сделать выводы о перспективности добычи нетрадиционных углеводородных ресурсов, а также оценить необходимость исследования нетрадиционных углеводородных источников в странах, ориентированных на использование традиционных ресурсов.

Ключевые слова: нефть, газ сланцевых толщ, плотные песчаники, иентрально-бассейновый газ, битуминозные пески, горючие сланщьы, сланцевая нефть

\section{Article info}

Received: 21 March 2020

Accepted: 20 November 2020

Available online: 7 December 2020 